Abstracta Iranica Abstracta Iranica

Revue bibliographique pour le domaine irano-aryen

Volume 29 | 2008

Comptes rendus des publications de 2006

\title{
Ensān va ḥeyvān. Mardom-šenāsī-ye ensān va heyvān-e ahli. Tehrān, Našr-e Afkār, 1385 [2006], 486 p.
}

\section{Rédaction}

\section{(2) OpenEdition}

1 Journals

Édition électronique

URL : http://journals.openedition.org/abstractairanica/31972

DOI : 10.4000/abstractairanica.31972

ISSN : 1961-960X

\section{Éditeur :}

CNRS (UMR 7528 Mondes iraniens et indiens), Éditions de l'IFRI

\section{Édition imprimée}

Date de publication : 15 mai 2008

ISSN : 0240-8910

\section{Référence électronique}

Rédaction, «Ensān va heyvān. Mardom-šenāsī-ye ensān va ḥeyvān-e ahlī. Tehrān, Našr-e Afkār, 1385 [2006], 486 p. », Abstracta Iranica [En ligne], Volume 29 | 2008, document 352, mis en ligne le 15 septembre 2008, consulté le 26 septembre 2020. URL : http://journals.openedition.org/ abstractairanica/31972 ; DOI : https://doi.org/10.4000/abstractairanica.31972

Ce document a été généré automatiquement le 26 septembre 2020.

Tous droits réservés 


\section{Ensān va ḥeyvān. Mardom-šenāsī-ye ensān va heyvā̄n-e ahlī. Tehrān, Našr- e Afkār, 1385 [2006], 486 p.}

\section{Rédaction}

1 Traduction, par Asqar Karimi, de L'homme et les animaux domestiques. Anthropologie d'une passion, Paris, Fayard (coll. " Le Temps des Sciences »), 1990, 325 p., vaste synthèse et remise à plat, par un ethnologue, du problème de la domestication animale, domaine jusque-là réservé aux zoologues et aux archéologues. L'A. étant iranologue, de nombreux exemples sont puisés dans le monde iranien.

INDEX

Thèmes : 12.1. Iran

\section{AUTEURS}

RÉDACTION

Directeur de la revue et secrétariats (Paris et Téhéran) 